\title{
What Controls the Availability to Animals of Detritus Derived from Vascular Plants: Organic Nitrogen Enrichment or Caloric Availability?*
}

\author{
Kenneth R. Tenore \\ Skidaway Institute of Oceanography, Post Office Box 13687, Savannah, Georgia 31406, USA
}

\begin{abstract}
Detritus derived from marsh grass with high available caloric content was mineralized and incorporated by the polychaete Capitella capitata at a significantly higher rate than detritus from marsh grass with available caloric content more typical of naturally-occurring Spartina alterniflora. Detritus derived from vascular plant material is usually low in nitrogen content, so nitrogen enrichment via microbial activity may increase nitrogen content over time. Detritus research has emphasized the microbial role in protein enrichment. However, such detritus is also composed mostly of structural material not generally assimilable by macroconsumers. Microbial decomposition results in transformation products whose energy content is available to macroconsumers. Our results suggest that available energy and not necessarily nitrogen content, can limit the utilization of marsh grass detritus to the macroconsumer.
\end{abstract}

\section{INTRODUCTION}

The nutritional value of detritus has been linked to microbes associated with the detritus particles (Newell, 1965; Frankenberg and Smith, 1967; Fenchel, 1972). Because detritus derived from vascular plant material, such as marshgrass Spartina alterniflora (Loisel), is typically low in nitrogen content, microbial 'protein enrichment' has been emphasized in detrital research (Harrison and Mann, 1975; Odum and Heald, 1975; Zieman, 1978). Decomposition is thus viewed as a process by which an increase in microbes (and their products) increases the nitrogen content of particulate organic detritus. Indeed, recently (Findlay and Tenore, 1982) we demonstrated with ${ }^{15} \mathrm{~N}$ tracer techniques that the deposit-feeder, Capitella capitata, when fed on low-nitrogen marsh grass, did incorporate microbial nitrogen, but that the worm derived a major portion of its nitrogen from the plant substrate per se when fed on seaweed-derived detritus.

Vascular plant material is also typically resistant to decay (Cummings et al, 1973; Gosselink and Kirby, 1974; Harrison and Mann, 1975) and is appreciably available to macroconsumers only after months of age-

\footnotetext{
- This research was supported by the Oceanography Section of the National Science Foundation (Grant DES82-00385)
}

ing (Tenore, 1975; Tenore et al., 1977; Tenore and Hanson, 1980). Fell et al. (1980) suggested that the slow rate of decomposition of mangrove detritus was caused by available carbon limiting nitrogen immobilization. Such detritus is typically composed in great part of highly-complexed structural materials (McIntire and Dunstan, 1976) that most macrobenthic detritus feeders cannot assimilate. Many detritivores are deficient in digestive enzymes capable of hydrolyzing cellulose, xylan, and other structural carbohydrates comprising the bulk of detritus (Hylleberg-Kristensen, 1972; but see Kofoed, 1975; and Foulds and Mann, 1978 for data on cellulose digestion by invertebrates). Thus the availability of bound energy in great part depends on microbes that enzymatically depolymerize the detritus into breakdown products (or microbial biomass and excretory products) assimilable by the macroconsumer.

The question arises as to what biochemical component, either directly or via effects on rates of microbial activity, limits the nutritional quality of vascular plant detritus to the macroconsumer. Growth studies of the polychaete Capitella capitata (Fabrius) cultured on a variety of sources of detritus indicated that an interaction of nitrogen and 'available' caloric content affected the nutritional quality of detritus (Tenore, 1981). Available caloric content, defined arbitrarily as that portion 
Table 1. Effect of available caloric content on mineralization and incorporation rates of detritus derived from marsh grass. Values are given as mean \pm 1 standard deviation of 2 replicates

\begin{tabular}{|c|c|c|c|c|c|c|}
\hline Stock & $\stackrel{\%}{\text { nitrogen }}$ & $\begin{array}{l}\text { Total Kcal } \\
\text { g dry wt. }\end{array}$ & $\begin{array}{c}\% \\
\text { of calories } \\
\text { available }\end{array}$ & $\begin{array}{c}\% \\
\text { ash-free } \\
\text { dry wt. }\end{array}$ & $\begin{array}{l}\text { Mineralization } \\
\text { (mg detritus } d^{-1} \text { ) }\end{array}$ & $\begin{array}{l}\text { Incorporation by } \\
\text { Capitella capitata } \\
\text { ( } \mu \text { g detritus mg } \\
\left.\text { dry wt worm }{ }^{-1} \mathrm{~d}^{-1}\right)\end{array}$ \\
\hline S- 6 & $1.0 \%$ & $4.45 \pm 0.42$ & $13 \pm 1$ & 93 & $35 \pm 7$ & $30 \pm 5$ \\
\hline$S-13$ & $0.9 \%$ & $2.61 \pm 0.06$ & $44 \pm 1$ & 89 & $60 \pm 6$ & $574 \pm 47$ \\
\hline
\end{tabular}

of total caloric content hydrolyzed by $1 \mathrm{~N} \mathrm{HC} 1$ for $6 \mathrm{~h}$ at $20^{\circ} \mathrm{C}$, is presumed to be a rough index of energy potentially easily utilized by macroconsumers. The importance of nitrogen versus available caloric content to the growth of the polychaete depended on the source of detritus. Detritus from vascular plants is typically low in both nitrogen $(<1 \%)$ and in available caloric content $(10$ to $15 \%$ of total calories for marsh grass compared to 30 to $50 \%$ of total calories for seaweed detritus). The growth of worms fed low nitrogen diet rations of seaweed detritus correlated best with nitrogen content; growth of worms fed vascular plant detritus correlated best with available calories. Microbial biomass and activity showed similar relations to detritus composition (Hanson, 1982).

In isotope tracer feeding experiments, the addition of organic nitrogen (casein-albumin) to fresh marsh grass detritus did not increase detritus mineralization or incorporation by Capitella capitata. In contrast, nitrogen added to easily-decomposable seaweed detritus did increase availability (Tenore et al., 1979). Thus caloric and not nitrogen availability to macroconsumers could limit their utilization of vascular plant detritus.

Nitrogen-available caloric effects are usually difficult to separate. Detritus from vascular plants is typically low both in nitrogen and available calories while detritus from seaweed is typically high in both components. However, structural (fiber, lignin) content of marsh grasses can vary with environmental conditions. We had the opportunity to grow marsh grass hydroponically (resulting in less structural material) while labelling it with ${ }^{14} \mathrm{C}$. Subsequent tracer experiments compared its availability to Capitella capitata of this low nitrogen-high available caloric content detritus to a low nitrogen-low available caloric content detritus more typical of marsh grass.

\section{MATERIALS AND METHODS}

Two stocks of the labelled marsh grass detritus characterized by different available caloric contents were prepared from plants growing in an enclosed chamber with $\left[{ }^{14} \mathrm{C}\right] \mathrm{CO}_{2}$ (Ferguson and Williams, 1974 , as modified by Tenore, 1979). Small seedlings were collected from the field and placed in pots in their natural sediment or in artificial media (Deco hydroponic rocks and nutrients). After $4 \mathrm{mo}$, a length of time sufficient for net growth of homogeneously-labelled tissue, the two plant stocks were freeze-dried and ground to pass a $180 \mu \mathrm{m}$ mesh.

Organic nitrogen levels were determined by replicated analysis with an elemental analyzer (PerkinElmer 240) and total and 'available' caloric values with a Parr microbomb calorimeter. Determination of available calories followed the method of Tenore (1981) described above. Ash-free dry weight (AFDW) was determined by weight loss after ashing at $475^{\circ} \mathrm{C}$ for $12 \mathrm{~h}$.

Detritus mineralization and incorporation by Capitella capitata were measured in microcosms by tracer techniques described in detail elsewhere (Tenore et al., 1979; Tenore and Hanson, 1980).

\section{RESULTS AND DISCUSSION}

The detritus derived from marsh grass with high available caloric content was mineralized and incorporated by the worms at a significantly higher rate than detritus from the marsh grass with available caloric content more typical of naturally-occurring Spartina alterniflora (Table 1). Both stocks had equivalent nitrogen content. Total caloric content of the more available stock was much lower than the more typical stock of marsh grass, presumably because of the lesser amount of highly-complexed structural material.

These data, along with our previous finding that organic nitrogen supplement to marsh grass detritus did not increase availability (Tenore et al., 1979), suggest that available energy content, and not necessarily nitrogen, can limit the availability of marsh grass detritus to the macroconsumer. This effect could be on the direct availability of the marsh grass detritus to the macroconsumer or through the effect on the rate at which microbes can degrade the highly-complexed structural materials. The previous study of nitrogen- 
supplement effects (Tenore et al., 1979) showed a positive correlation of microbial biomass (total adenylates) with increasing detritus oxidation due to increasing nitrogen supplement of the low nitrogen seaweed detritus. In all of our studies, the microbes have been responsible for most of the detritus oxidation.

Our results suggest that investigations to understand energy flow in detritus-based systems should include factors affecting the rates of microbial degradation and caution must be used in using total caloric content as an index of nutritional value.

\section{LITERATURE CITED}

Cummings, K. W., Peterson, R. C., Howard, F. D., Wuycheck, J. C., Holt, V. I. (1973). The utilization of leaf litter by stream detritivores. Ecology 54: 336-345

Fell, J. W., Master, I. M., Newell, S. Y. (1980). Laboratory model of the potential role of fungi in the decomposition of red mangrove leaf litter. In: Tenore, K. R., Coull, B. C. (eds.) Marine benthic dynamics. University of South Carolina Press, Columbia, pp. 359-372

Fenchel, T. (1972). Aspects of decomposer food chains in marine benthos. Verh. dt. zool. Ges. 65: 14-22

Ferguson, R. L., Williams, R. B. (1974). A growth chamber for the production of ${ }^{14} \mathrm{C}$-labelled salt marsh plants and its application to smooth cordgrass, Spartina alterniflora Loisel. J. exp. mar. Biol. Ecol. 14: 251-259

Findlay, S., Tenore, K. R. (1982). Nitrogen source for the detritivore polychaete, Capitella capitata: detritus substrate or microbes? Science, N.Y. 218: 371-372

Foulds, J. B., Mann, K. H. (1978). Cellulose digestion in Mysis stenolepis and its ecological implications. Limnol. Oceanogr. 23: 760-766

Frankenberg, D., Smith, K. L., Jr. (1967). Coprophagy in marine animals. Limnol. Oceanogr. 12; 443-450

Gosselink, J. G., Kirby, C. J. (1974). Decomposition of salt marsh grass, Spartina alterniflora Loisel. Limnol. Oceanogr. 19: 825-831

Hanson, R. B. (1982). Organic nitrogen and caloric content. II. Microbial biomass and activity. Estuar. coast. Shelf Sci. 14: $325-336$

Harrison, P. G., Mann, K. H. (1975). Detritus formation from eelgrass (Zostera marina): the relative effects of fragmentation, leaching, and decay. Limnol. Oceanogr. 29: 924-934

Hylleberg-Kristensen, J. (1972). Carbohydrates of some marine invertebrates with notes on their food and on the natural occurrence of the carbohydrase studied. Mar. Biol. 14: $130-142$

Kofoed, L. H. (1975). The feeding behavior of Hydrobia ventrosa Montague. II. Allocation of the components of the carbon budget and the significance of the secretion of dissolved organic material. J. exp. mar. Biol. Ecol. 19: 243-256

McIntire, G., Dunstan, W. (1976). Seasonal measurements of carbon, nitrogen, ash, iron, carbohydrates and pigments from geographically different Spartina alterniflora marshes in the southeast. Ga. Mar. Science Center Technical Report Series \# 76-5

Newell, R. C. (1965). The role of detritus in the nutrition of two marine deposit feeders, the prosobranch Hydrobia ulvae and the bivalve Macoma balthica. Proc. zool. Soc. Lond. 144: 25-45

Odum, W. E., Heald, E. J. (1975). The detritus food web of an estuarine mangrove community. In: Cronin, L. E. (ed.) Estuarine research, Vol. 1. Academic Press, New York, pp. 265-286

Tenore, K. R. (1975). Detrital utilization by the polychaete, Capitella capitata. J. mar. Res. 33 (3): 261-274

Tenore, K. R. (1977). Utilization of aged detritus derived from different sources by the polychaete, Capitella capitata. Mar. Biol. 44: 51-55

Tenore, K. R. (1981). Organic nitrogen and caloric content of detritus. I. Utilization by the deposit-feeding polychaete Capitella capitata. Estuar. coast. mar. Sci. 12: 39-47

Tenore, K. R., Hanson, R. B. (1980). Availability of different detritus with aging to a polychaete macroconsumer, Capitella capitata. Limnol. Oceanogr. 25: 553-558

Tenore, K. R., Tietjen, J. H., Lee, J. J. (1977). Effect of meiofauna on incorporation of aged eelgrass, Zostera marina, detritus by the polychaete Nephthys incisa. J. Fish. Res. Bd Can. 34: 563-567

Tenore, K. R., Hanson, R. B., Dornseif, B. E., Wiederhold, C. N. (1979). The effect of organic nitrogen supplement on the utilization of different sources of detritus. Limnol. Oceanogr. 34: 350-355

Zieman, J. E. (1978). Quantitative and dynamic aspects of the ecology of turtle grass, Thalassia testudinum. In: Cronin, L. E. (ed.) Estuarine research, Vol. 1. Academic Press, New York, pp. 541-562 